\title{
Manajemen dan Strategi Dakwah Pengajian Ikatan Sosial Kerukunan Air Sengak Rejang Lebong
}

\author{
Murniyanto \\ Institut Agama Islam Negeri Curup \\ murniyanto@iaincurup.ac.id
}

\begin{abstract}
The purpose of this study was to determine the management and da'wah strategy of the ISK Air Sengak Rejang Lebong study. The method is by interviewing the leader of the recitation of the ISK Air Sengak Rejang Lebong recitation, using the library, the author using a reference book, documents accompanied by monthly recitation reports to strengthen the data. The results obtained by the author of Islamic preaching are: (a) applying the teachings of taubid in the content of da'wah, (b) applying to the community about the teachings of Islam so that people understand the teachings of Islam and want to implement them and practice them so that there are changes in daily life (c) applying imprative da'wah to members of social ties, water harmony is carried out in monthly recitation of ISK mingling with the community and other Muslims, especially on Rt.7,8 and $9 \mathrm{R} w .3$ Air Sengak Rejang Lebong, (d) Overall management function as planning. So that what is done by members of the ISK orsos can be aimed at a good path.
\end{abstract}

Keywords: manajement; strategy; dakwab; ISK Recitation

\begin{abstract}
Abstrak
Tujuan penelitian ini adalah untuk mengetahui manajemen dan strategi dakwah pengajian ISK Air Sengak Rejang Lebong. Metode yaitu dengan cara wawancara pada pimpinan pengajian pengajian ISK Air Sengak Rejang Lebong,menggunakan perpustakaan,pada penulis menggunakan buku rujukan,dokumen disertai juga dengan laporan pengajian perbulanan untuk memperkuat data. Hasil yang didapatkan penulis cara berdakwah Islamiah yaitu: (a) menerapkan ajaran tauhid di dalam isi dakwah,(b)menerapkan pada masyarakat tentang ajaran agama Islam sehingga masyarakat mengerti tentang ajaran agama Islam serta mau melaksanakannya dan mengamalkannya sehingga ada perubahan dalam kehidupan sehari-hari,(c)menerapkan dakwah impratif pada anggota ikatan sosial kerukunan air sengak dilakukan dalam pengajian bulanan ISK membaur dengan masyarakat dan umat Islam lainnya terutama pada Rt.7,8 dan 9 Rw.3 Air Sengak Rejang Lebong,(d)Secara menyeluruh fungsi
\end{abstract}


$2 \mid \mathrm{Jurnal}$ Dakwah dan Komunikasi, Vol.6 No.1, 2021

manajemen sebagai perencanaan. Sehingga apa yang dikerjakan oleh anggota orsos Isk bisa ditujukan untuk jalan yang baik.

Kata Kunci: manajemen; strategi; dakwah; pengajian ISK

\section{Pendahuluan}

Dalam kita memperluaskan ajaran agama Allah, perlu adanya kekuatan iman dalam menghadapi berbagai macam rintangan. Oleh karena itu perlu usaha kita secara maksimal dalam menyampaikan dakwah, rintangan apapun yang kita temukan dalam berdakwah maka harus dihadapi secara istiqomah dalam menjalankan syariat Islam. Dakwah pada diri kita sendiri diperlukan dalam kehidupan yang serba modern seperti sekarang ini. Dakwah tersebut harus ditunjang oleh ilmu pengetahuan agama dan kalau kita kembali merujuk pada dakwah Rasullullah SAW ketika itu, maka ada dua hal cara beliau berdakwah yaitu dakwah yang disampaikan secara tersembunyi-sembunyi dan terang terangan, dakwah seperti ini sampai saat ini masih dilakukan oleh para pendakwah. Waktu demi waktu berganti, maka jiwa dan pemikiran yang positif serta kebermanfaatan bagi para pendakwah tentunya menjadi sumbangsih tersendiri bagi perjalanan dakwah yang ada pada saat ini.

Adanya pengelolaan pada masyarakat akibat tidak ada kesimbangan perkembangan secara teknis yang mempunyai kemampuan sosial, walau dalam keadaannya kemajuan ilmu pengelolaannya sangat lambat jika dibandingkan dengan keberadaan insan yang bumi ini yaitu mulai dari adanya Adam dan Hawa mulai kelihatan atau nampak. ${ }^{1}$

Manajer organisasi sosial adalah insan yang berada di organisasi sosial yang kuat dari sistem yang terarah dari organisasi. Organisasi sosial itu dibuat berdasarkan mupakat seluruh keanggotaannya. Manager organisasi sosial yaitu manajer organisasi ialah yang paling berperan dalam pembentukan sistem tersebut, oleh karena itu seorang manajer diharapkan orang yang berwawasan luas dan mampu mengelola organisasi. $^{2}$

Pengelolaan semua aktivitas yang dibuat dalam visi misi menuju organisasi sosial serta sumberdaya dengan baik sehingga dari masa ke masa akan terwujud dengan memberdayakan sedikit sumberdaya yang tersedia. ${ }^{3}$

Manajemen merupakan rangkaian kegiatan yang telah dirancang sedemikian rupa yang bertujuan untuk mencapai tujuan organisasi yang telah disepakati bersama. Dimana dalam kegiatan manajemen tersebut memerlukan sumber daya secara efisien dan efektif. Efektif dimaknai sebagai ketercapaian tujuan yang ditetapkan, sedangkan efisien dimaknai sebagai ketercapaian tujuan dengan menggunakan sedikit mungkin sumber daya yang tersedia.

${ }^{1}$ Siswanto, Pengantar Mananajemen (Jakarta: Bumi Aksara, 2011).

${ }^{2}$ Murni Yanto, "Manajemen Sekolah Dalam Pengelolaan Kegiatan Guru Bahasa Indonesia Di Sekolah Dasar," Jurnal Estetik 3, no. 1 (2020): 15-26, https://doi.org/DOI:10.29240/estetik.V31i.1479.

${ }^{3}$ Murni Yanto, "Manajemen Dan Mutu Pembelajaran Bahasa Indonesia Di SMPN 4 Rejang Lebong," Jurnal Ar-Riayah 1, no. 2 (2017): 192, https://doi.org/DOI :http:/dx.doi.org/10.29240/jpd.v1i2-319. 
Menurut Piaget (dalam Mgs. Nazarudin) bahwa Manajemen adalah serangkaian kegiatan yang didesain untuk mencapai tujuan organisasi dengan menggunakan sumber daya secara efisien dan efektif dan dilakukan dalam lingkungan yang senantiasa berubah dari waktu ke waktu. ${ }^{4}$ Efektif berarti tercapai tujuan yang ditetapkan dan efisien berarti mencapai tujuan dengan menggunakan sedikit mungkin sumber daya yang tersedia.

Pada kehidupan sehari-hari bahwa manajemen dakwah dalam pengajian ISK Rejang Lebong, masalah yang utama dalam hal ini adalah untuk mengajak serta membawa semua aspek pada kehidupan insan dengan menerapkan pengelolaan dakwah. Di sisi lain, ada juga beberapa problem yang harus menjadi perhatian bersama, Kita mengetahui kekuatan serta ketidakberdayaan dalam organisasi sosial kita, juga pengelola melakukan metode yang baik melaksanakan aktivitas organisasi.

Dengan demikian, sebuah organisasi atau lembaga dakwah membutuhkan manajemen untuk mengatur dan menjalankan aktivitasnya sesuai dengan tujuantujuannya. Karena dengan adanya manajemen, maka terdapat mekanisme yang menjamin untuk menyelesaikan kewajiban dan mendapatkan hasil baru sesuai dengan proses yang diatur. Dengan manajemen suatu kegiatan dapat diselesaikan dengan kewajiban-kewajiban sebagai ganti dari tugas sebelumnya. Sebuah organisasi atau aktivitas jika dilaksanakan dengan manajemen dapat diketahui secara utuh kapasitas kemampuannya dan menunjukkan jalan yang paling utuh untuk mewujudkan tujuan-tujuannya.

Metode penelitian dalam ilmu sosial dengan menganalisis data berupa katakata (lisan maupun tulisan) serta perbuatan-perbuatan insan serta peneliti tidak menghitung atau mengkuantifikasikan data kualitatif, jadi tidak menganalisis angkaangka. Data yang dianalisis kualitatif adalah kata-kata dan perbuatan manusia. ${ }^{5}$ Penelitian ini dilakukan dalam ilmu-ilmu sosial, penelitian ini digunakan secara orisinil. ${ }^{6}$

\section{Hasil dan Pembahasan}

\section{Manajemen Dakwah}

Pada hakikatnya organisasi mempunyai peran yang kuat dengan adanya pengelolaan yang didorong sumber daya manusia, serta sarana prasarana dalam hal ini pengelola harus menggunakan secara baik dan professional untuk menjalankan visi misi serta perkembangan pada organisasi sosial.

Dalam istilah manajemen atau pengelolaan yang mempunyai arti seni melaksanakan atau mengatur, mengelola, mengarahkan serta mengawasi. Jadi pengelolaan merupakan aktivitas dari berbagai sumber data serta bisa menyatukan

\footnotetext{
${ }^{4}$ Mgs. Nazarudin, Manajemen Pembelajaran Implementasi Konsep, Karakteristik Dan Metodologi Pendidikan Agama Islam Di Sekolab Umum (Yogyakarta: Teras, 2007).

${ }^{5}$ Afrizal, Metode Penelitian Kualitatif Sebuah Upaya Mendukung Penggunaan Penelitian Kualitatif Dalam Berbagai Disiflin Imu (Jakarta: Rajawali Pers, 2015).

${ }^{6}$ Murni Yanto dan Irwan Fathurrahman, "Manajemen Kebijakan Kepala Madrasah Dalam Meningkatkan Mutu Pendidikan," Jurnal Konseling Dan Pendidikan 7, no. 3 (2019): 123 30, https://doi.org/http://doi.org/10.29210/138700.
} 
4 Jurnal Dakwah dan Komunikasi, Vol.6 No.1, 2021

dengan sesama anggota dengan proses tertentu untuk mencapai organisasi sosial secara efektif dan efisien. ${ }^{7}$

Manajemen atau pengelolaan dalam artian seni suatu organisasi dalam menjalankan aktivitas untuk mewujudkan serta mengembangkan visi misi organisasi yang memiliki spiritual keagamaan, pengendalian diri, kepribadian, kepercayaan, kecerdasan, aqidah, akhlak, tauhid serta skill yang mempuni yang diperlukan dirinya,masyarakat,bangsa dan negara. Pengelolaan organisasi dengan tujuan untuk mencapai sumber daya yang kuat serta didalamnya mempunyai pengaruh terhadap dakwah baik dengan menggunakan informasi dan teknologinya. ${ }^{8}$

Pengelolaan dibutuhkan untuk memperkuat organisasi guna memenuhi efektivitas pelaksanaan dakwah. Efektif yaitu melaksanakan kegiatan secara penuh dengan program yang ditetapkan sehingga aktivitas dilaksanakan dengan benar. ${ }^{9}$

\section{Fungsi manajemen :}

1) Perencanaan, penerapan aktivitas dalam menunjang visi misi organisasi dimasa mendatang untuk memenuhi harapan tertentu. ${ }^{10}$

2) Fungsi dalam pengelolaan adalah menjalankan ketentuan yang berlaku dalam perencanaan tertentu. Dalam pengelolaan harus ada pengkajian kekuatan dan ketidak berdayaan orsos serta membuat ancaman,tantangan hambatan dan gangguan dan kebijakan program tertentu. ${ }^{11}$

3) Organisasi, yaitu pemberian aktivitas mulai dari yang terkecil sampai pada yang terbesar dan ditugaskan pada keahliannya serta berkoordinasi dengan ketua organisasi. ${ }^{12}$

3. Pengarahan, motivasi untuk membuat dorongan dalam orsos

4. Pengawasan, memperhatikan apa aktivitas yang sudah dilakukan,apakah efektif melalui pengelolaan yang berstandar.

Aktivitas pelaksanaan program harus dilaksanakan kerjasama dengan warga atas panduan dalam aktivitas orsos berdasarkan hasil musyarawah dari aktivitas bulanan.

\section{Manajemen Dakwah}

Pelaksanaan dakwah bisa berlangsung secara baik bila dilakukan dengan mngetahui kendala-kendala dihadapi dalam warga masyarakat. Sesudah itu,dalam memahami keadaan tempat berdakwah, kita buat suasana yang nyaman dari berbagai situasi.

Persoalan dalam masyarakat mengharuskan seorang Dai wajib membuat perencanaan yang unggul untuk mengatur serta mengorganisasikan dakwah upaya

\footnotetext{
${ }^{7}$ Arifin M. Dan Barnawi, Manajemen Sarana Dan Prasarana Sekolah (Yogyakarta: ArRuzz Media, 2012).

${ }^{8}$ Hartani A.L, Manajemen Pendidikan (Yogyakarta: Laks Bang Pressindo, 2011).

${ }^{9}$ Hartani A.L.

${ }^{10}$ Syaiful Sagala, Konsep Dan Makna Pembelajaran (Bandung: Alfabeta, 2011).

${ }^{11}$ Syaiful Sagala.

12 S.Shoimatul Ula, Revolusi Belajar (Yogyakarta: Ar-Ruzz Media, 2013).
} 
menyatukan dengan menyiar ajaran-ajaran Islam dalam masyarakat modern ini.dan pengelolaan dakwah harus lebih baik.

Seorang da'i harus efisien dalam menyampaikan dakwahnya kepada masyarakat agar mudah dipahami serta dimengerti, demi untuk mendukung metodenya yang baik,serta agenda program orsos harus akurat agar pendakwahnya lebih terarah dalam penyampaiannya. Seorang da'i harus menyampaikan tataran praktis,supaya kegiatan bulanannya selalu diramaikan oleh masyarakat dari ketiga RT yang dimasyarakat Air Sengak Curup,dibutuhkan juga pengurus orsos untuk mendukung pencapaian tujuan dari visi misi pada organisasi.

Pada konteks ini,pengelolaan dibutuhkan untuk mengetahui atau memahami supaya dakwah cocok pada sasaran dan mencapai harapan sehingga aktivitas seorang da'I melakukan serta mengelola dengan akurat untuk memenuhi tujuan.

\section{Langkah-langkah Manajemen Dakwah}

Dakwah berarti panggilan, seruan atau ajaran. Dakwah yaitu seruan untuk insan secara bijaksana dalam lindungan hidayah Allah serta Nabinya. ${ }^{13}$

Dakwah sebagai usaha mengajak manusia dengan cara bijaksana kepada jalan yang benar. Metode dakwah yaitu aktivitas yang dilakukan secara tepat,terprogram dan terencana serta eksperimen ilmiah untuk menggapai harapan yang sudah ditetapkan. ${ }^{14}$

Untuk melaksanakan manajemen dakwah dengan sungguh-sungguh,perlu langkah-langkah yang harus dilaksanakan oleh seorang da'i : Perlu perencanaan yang unggul (matang). Rangkaian aktivitas yang dibuat dari perencanaan dakwah harus terarah, integrasi,istiqomah,Allah menyeruhkan kepada umat yang beraqidah agar melakukan dakwah demi kepentingan umat akan datang lebih mulia.

Dalam kaitan ini kegiatan manajemen dakwah berlangsung pada tataran kegiatan dakwah itu sendiri. Dimana setiap aktivitas dakwah khususnya dalam skala organisasi atau lembaga untuk mencapai suatu tujuan dibutuhkan sebuah pengaturan atau manajerial yang baik, ruang lingkup kegiatan dakwah merupakan sarana atau alat pembantu pada aktivitas dakwah itu sendiri.

Ada beberapa kebaikan apabila aktivitas atau kegiatan dakwah direncanakan dengan matang:

a) pelaksanaan dakwah harus secara terus menerus.Kegiatan dakwah dalam organisasi ISK tidak akan berhasil,bila tidak direncanakan secara matang.

b) Untuk acara dakwah organisasi ISK sering menggunakan kegiatan diskusi Dalam hal ini perlu perencanaan yang matang dan terpadu.

c) perlu perencanan supaya tidak terjadi pemborosan energy dan waktu.

d) kekurangan si penceramah dalam berita yang di perlukan pengetahuan yang digunakan untuk dakwah dalam organisasi dakwah ini suatu kegiatan yang kolektif.

Adapun Fungsi Manajemen yang dilakukan pada Organisasi ISK meliputi:

${ }^{13}$ Wahidin, Pengantar Ilmu Dakwah (Jakarta: Rajawali Pers, 2011).

14 suwito Masykuri dan Armai Abuddin, Integrasi Ilmu Agama Dan Ilmu Umum (Jakarta: RajaGrafindo Persada, 2005). 
6|Jurnal Dakwah dan Komunikasi, Vol.6 No.1, 2021

Fungsi Perencanaan. Menurut G.R. Terry, Planning atau perencanaan adalah tindakan memilih dan menghubungkan fakta dan membuat serta menggunakan asumsi-asumsi mengenai masa yang akan datang dalam hal memvisualisasikan serta merumuskan aktivitas-aktivitas yang diusulkan yang dianggap perlu untuk mencapai hasil yang diinginkan. ${ }^{15}$

Sebelum manajer dapat mengorganisasikan, mengarahkan atau mengawasi, mereka harus membuat rencana-rencana yeng memberikan tujuan dan arah organisasi. Dalam perencanaan, manajer memutuskan "apa yang harus dilakukan, kapan melakukannya, bagaimana melakukannya, dan siapa yang melakukannya". Jadi, perencanaan adalah pemilihan sekumpulan kegiatan dan pemutusan selanjutnya apa yang harus dilakukan, kapan, bagaimana dan oleh siapa.

Perencanaan merupakan proses pemikiran dan pengambilan keputusan yang matang dan sistematis, mengenai tindakantindakan yang akan dilakukan pada masa yang akan datang. Perencanaan yang akan dilakukan harus disesuaikan dengan keadaan situasi dan kondisi pada masa lampau, saat ini, serta prediksi masa depan.

Perencanaan dalam organisasi meliputi program kerja yang akan dilakukan, diantaranya: 1) Melaksanakan kegaiatan rutin organisasi ISK sesuai fungsi organisasi berdasarkan ketentuan AD, ART agar tetap berjalan sebagaimana mestinya; 2) Melaksanakan rapat-rapat pengurus untuk membahas berbagai permasalahan organisasi serta menyempurnakan ketentuan yang dipandang perlu untuk ditinjau ulang agar keberadaan organisasi lebih baik; dan 3) Mengupayakan sumber dana dari pihak donatur yang sifatnya tidak mengikat untuk penyempurnaan pembuatan ruang sekretariat dan perawatan gedung serbaguna ISK. antara lain : a. Rehab Bangkubangku meja santri MDA ISK; b. Pembangunan gedung serba guna ISK bertingkat; dan c) Lemari arsip.

Selain fungsi perencanaan, pengajian ISK juga menerapkan fungsi pengorganisasian. Fungsi Pengorganisasian ISK dijabarkan sebagai berikut:

Keberadaan Organisasi ISK merupakan salah satu Organisasi bersifat sosial memegang peranan penting dalam kehidupan bermasyarakat baik dalam suasana suka dan duka. Hal ini mengandung hikmah bahwa manusia itu adalah makhluk sosial tidak dapat hidup tanpa bantuan manusia lainnya atau dengan kata lain tiada kehidupan tanpa hubungan (komunikasi) dengan manusia lainnya, melalui Organisasi ISK telah membuktikan berbagai masalah kehidupan bermasyarakat dapat diatasi.

Sebagaimana telah ditetapkan dalam Anggaran Rumah Tangga (ART) Organisasi ISK Bab IV, Pasal 7 ayat 2 halaman 2 tentang kepengurusan dan wewenang dimana pengurus dipilih melalui Rapat Anggota untuk satu Masa Jabatan lamanya adalah 2 (dua) tahun dan dapat dipilih kembali berpedoman pada ketetapan tersebut diatas, kepengurusan organisasi ISK masa bakti 2016 - 2019 berakhir pada tanggal 4 juni 2019.

Adapun Visi dan Misi Organisasi ISK adalah Ketulusan hati dalam menjalankan tugas kepengurusan Organisasi ISK merupakan pengabdian yang mulia karena Organisasi ISK mempunyai tujuan kedepan sesuai dengan Visi dan Misinya adalah sebagai berikut :

\footnotetext{
${ }^{15}$ Iwan Purwanto, Manajemen Strategi (Bandung: Yrama Widya, 2006).
} 
Adapun Visi organisasi ini adalah: 1) Mewujudkan insan takwa yang memiliki wawasan serta pengetahuan yang luas berdasarkan syariat agama islam melalui Organisasi Sosial ISK; dan 2) Terciptanya ikatan silaturahmi yang kuat antara sesama warga masyarakat, rukun dan senantiasa saling membantu dilandasi oleh rasa memiliki Organisasi

Kemudian Misi adalah 1) Memberikan pelayanan kepada anggota ISK sesuai dengan fungsinya berdasarkan ketetapan dan Program Kerja Organisasi; 2) Melaksanakan pengajian-pengajian bulanan secara tertib dan terjadwal kepada Anggota ISK serta berupaya menampilkan penceramah yang berkualitas; dan 3) Mengutamakan prinsip bermusyawarah menuju mufakat dalam mengatasi berbagai masalah organisasi dan kehidupan bermasyarakat.

Melalui Rapat Anggota Tahunan ini kami menghimbau mari kita menfaatkan sebaik mungkin untuk saling bertukar fikiran dan menemukan solusi terbaik demi kemajuan Organisasi dimasa mendatang akhirnya lebih dan kurang mohon dimaafkan semoga Allah SWT memberkati upaya kita bersama Amin, Amin Yarobbal Alamin.

\section{Gambaran Umum Perkembangan Organisasi ISK Dan Pelaksanaan Program Kerja}

Setelah para manajer menetapkan tujuan-tujuan dan menyusun rencanarencana atau program-program untuk mencapainya, maka mereka perlu merancang dan mengembangkan suatu organisasi yang akan dapat melaksanakan berbagai program tersebut secara sukses.

Pengorganisasian (organizing) adalah 1) penentuan sumber daya-sumber daya dan kegiatan-kegiatan yang dibutuhkan untuk mencapai tujuan organisasi, 2) perancangan dan pengembangan suatu organisasi kelompok kerja yang akan dapat membawa hal-hal tersebut kearah tujuan., 3) penugasan tanggung jawab tertentu dan kemudian, 4) pendelegasian wewenang yang diperlukan kepada individu-individu untuk melaksanakan tugas-tugasnya. Fungsi ini menciptakan struktur formal dimana pekerjaan ditetapkan, dibagi dan dikoordinasikan. ${ }^{16}$

Dalam kepengurusan Organisasi ISK masa bakti 2016 - 2019 telah melaksanakan kegiatan berbagai bidang adalah sebagai berikut :

\section{a. Bidang Organisasi}

1. Susunan Pengurus

Susunan Pengurus ISK berdasarkan keputusan rapat pengurus dan anggota tanggal 4 juni 2016 tentang Pembentukan Pengurus Organisasi ISK masa bakti 2016 - 2019 dan Keputusan Rapat Pengurus ini lengkap tanggal 15 Juni 2016 tentang Alih Tugas Pengurus yang dipandang perlu. Adapun susunan komposisi pengurus adalah sebagai berikut :
I.
Pembina
: Lurah Kelurahan Talang Rimbo Baru Curup
II. Penasehat
: 1. Drs. H. Tarmizi Syam
2. Drs. Syukur Hamidi

16 T.Hani Handoko, Manajemen (Yogyakarta: BPFE, 2004). 
8 Jurnal Dakwah dan Komunikasi, Vol.6 No.1, 2021

III. Tim Pemeriksa Keuangan

Ketua

Sekretaris

Anggota

IV. Pengurus Harian

Ketua Umum

Wakil

Sekretaris

Wk. Sekretaris

Bendahara

V. Seksi - seksi

: Hasian Lupi

: Yuharman

: Burhanuddin,A.Ma.Pd

: Murni yanto

: Sainil.R

: H.M.Tanwir

: Yuhmir,S.Pd.I

: Mudisman, S.Pd

a. Penyelenggara Jenazah Laki - laki
1. Maha Utama
2. Samawar

b. Penyelenggara Jenazah Perempuan
1. Rosni Nur
2. Ernawati,A.Ma.Pd

c. Penyiapan Makam / Penggali Kubur
1. Supandi
2. Yanto Tukidi

d. Pengajian dan Kunjungan Ta'ziah
1. Sumarlin,S.KM
2. Amrizal,S.Pd

e. Pendidikan dan Keterampilan serta SDM
1. Sofrin,A.Ma.Pd
2. Mulyono

f. Pembangunan dan Kesejahteraan
1. Mursito St. Datuk
3. Wildan St. Hidayah
2. Aprizal Jambak
4. Dedi Hendrayana

g. Kesenian, Budaya dan Peranan Wanita

1. Santi Suhar 2. Leta

2. Santi Suhar 3.Saira 4. Epi 4. Jas

h. Humas dan Kunjungan Sosial

1. Wilayah I (Jl. Imam Bonjol/ : 1. Z. Abidin Ahmad Dahlan) : 2. Syaiful

2. Wilayah II (Jl. Taman Siswa/ : 1 . Supandi Gg. Belimbing) : 2. Supri

3. Wilayah III (Jl. Ahmad Marzuki) : 1. Suhardi

2. Edi

i. Perlengkapan Alat Tarup : 1. Yan Bor

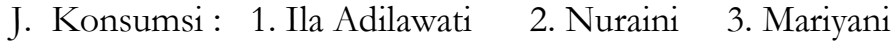

2. Jumlah anggota ISK 160 Orang

\section{b. Bidang Penyelenggara Jenazah}

Pengurus yang membidangi penyelenggaraan jenazah telah melaksanakan tugasnya dalam rangkaian kegiatan Fardhu Kipayah dengan baik sesuai wewenang dan tanggung jawabnya.

Dalam waktu 3 (tiga) tahun terhitung dari bulan juni 2016 sampai dengan bulan juli 2019 telah melaksanakan penyelenggaraan jenazah. 


\section{c. Bidang Penyiapan Makam / Kuburan}

Sejalan dengan kegiatan di bidang penyelenggaraan jenazah tersebut diatas, pengurus yang membidangi penyiapan makam telah melaksanakan tugas dengan baik dan senantiasa menjalin kerja sama dengan pihak yang mendapat musibah. Segala sesuatu berkaitan dengan dana Insentif petugas menyiapkan makam telah dibayar sesuai ketentuan Organisasi.

\section{d. Bidang Pengajian Bulanan / Dakwah dan kunjungan Takziah}

Beberapa kegiatan telah dilaksanakan oleh pengurus yang membidangi seksi pengajian bulanan / dakwah dan kunjunngan takziah bersama pengurus lainnya dalam waktu selama 2 (dua) tahun terhitung sejak bulan juni 2016 sampai dengan bulan juli 2019 telah dilaksanakan dengan rincian sebagai berikut:

1. Pengajian Bulanan terdiri dari :

a. Pengajian bulanan atas permintaan anggota ISK (di rumah anggota) telah dilaksanakan sebanyak 1 kali.

b. Pengajian yang dilaksanakan di gedung serbaguna ISK 20 kali untuk jelasnya data pengajian bulanan. Sedangkan pengajian bulanan pada bulan Ramadhan sebagaimana biasa ditiadakan.

Terhadap hal-hal yang berkaitan dengan penyiapan dana untuk pengajian bulanan seperti honor penceramah, konsumsi, transport seksi dakwah, mendatangkan guru / penceramah telah dibayarkan sesuai ketentuan organisasi.

2. Kunjungan Takziah

Kegiatan kunjungan takziah terhadap anggota ISK yang mendapat musibah (kematian) telah dilaksanakan oleh seksi dakwah, pengurus rutin, humas dan anggota ISK yang berkesempatan hadir. Dalam tahun 2014 -2016 telah dilaksanakan kunjungan takziah kepada anggota ISK yang mendapat musibah (kematian).

Pelaksanaan kunjungan takziah setiap malam pertama telah dikoordinir oleh seksi dakwah, baik dari mendatangkan guru pengatur jalannya takziah, demikian pula halnya pemberian uang duka untuk ahli musibah telah dibayar sesuai ketentuan organisasi.

\section{e. Bidang Humas dan Kunjungan Sosial}

\section{Bidang Humas}

Seksi humas merupakan salah satu bagian yang penting dalam menghimpun sumber dana untuk kepentingan organisasi secara umum telah melaksanakan tugas dan tanggung jawabnya meskipun dalam beberapa hal ditinjau dari segi. Administrasi keuangan masih perlu ditingkatkan dimasa mendatang.

2. Kunjungan Sosial

Pelaksanaan kunjungan sosial terhadap anggota ISK yang sakit hingga rawat nginap (Opname) di Rumah sakit oleh Humas bersama pengurus inti serta anggota ISK lainnya yang berkesempatan hadir, telah dilaksanakan 
10 Jurnal Dakwah dan Komunikasi, Vol.6 No.1, 2021

sebagaimana mestinya, meskipun terkadang pelaksanaannya agak tertunda karena keterlambatan informasi. Dalam tahun 2016-2019 telah dilaksanakan kunjungan sosial terhadap anggota ISK yang sakit (Opname di rumah sakit) sebanyak : orang dan kepada yang bersangkutan telah diberikan bantuan dana sosial sesuai ketentuan anggara organisasi ISK.

\section{f. Bidang Perlengkapan dan Alat Tarup}

Dalam hal memberikan pelayanan terhadap anggota ISK yang memerlukan perlengkapan alat tarup maupun peralatan lainnya seksi perlengkapan alat tarup telah melaksanakan tugas dan tanggung jawabnya, sesuai ketentuan dan prosedur pinjaman termasuk penetapan sewa atas persetujuan ketua organisasi ISK kecuali untuk keperluan mendesak (Musibah Kematian).

Guna kelancaran peminjaman perlengkapan alat tarup maupun peralatan lainnya pengurus senantiasa telah berupaya menertibkan administrasi pinjaman sesuai kemampuan dana yang tersedia memperhatikan kondisi alat tarup yang ada dan berdasarkan hasil pemeriksaan dan tim pemeriksaan barang Inventasi organisasi ISK menunjukkan bahwa pada peralatan tertentu masih perlu ditambah dan pemisahan peralatan yang tidak dilayak dipinjamkan guna memberikan pelayanan yang lebih baik pada anggota maupun non anggota dimasa mendatang.

\section{Realisasi Program Kerja Organisasi ISK Tahun 2016 - 2019}

1. Melaksanakan kegaiatan rutin organisasi ISK sesuai fungsi organisasi berdasarkan ketentuan AD, ART agar tetap berjalan sebagaimana mestinya.

2. Melaksanakan rapat - rapat pengurus untuk membahas berbagai permasalahan organisasi serta menyempurnakan ketentuan yang dipandang perlu untuk ditinjau ulang agar keberadaan organisasi lebih baik.

3. Mengupayakan sumber dana dari pihak donatur yang sifatnya tidak mengikat untuk penyempurnaan pembuatan ruang sekretariat dan perawatan gedung serbaguna ISK. antara lain :

a. Rehab Bangku-bangku meja santri MDA Isk

b. Pembangunan gedung serba guna ISK bertingkat

c. Lemari arsip

\section{Pelaporan}

Selanjutnya Fungsi Pelaporan merupakan salah satu fungsi manajemen. Laporan pertanggung jawaban Pengurus Organisasi Sosial kerukunan yang telah kita kenal dengan "ISK" masa bakti 2016 - 2019 ini, merupakan gambaran sejauh mana pelaksanaan Program Kerja dapat dicapai, dalam satu periode kepengurusan, tentunya keberhasilan pencapaian tersebut mengalami berbagai proses dan waktu tidak terlepas dari dukungan seluruh anggota dan upaya yang telah ditempuh oleh pengurus terdahulu.

Akhir kata selamat mengikuti Rapat Anggota Tahunan semoga Allah SWT senantiasa memberikan kekuatan, perlindungan serta petunjuk-Nya untuk mencapai kemajuan Organisasi ISK yang lebih baik dimasa mendatang. 


\section{Strategi Dakwah}

Strategi ialah solusi dengan penuh kekuatan dalam menuangkan pendapatpendapat,ide merencanakan dan melakukan suatu aktivitas pada waktu tertentu. ${ }^{17}$

Permulaan solusi dilakukan dalam sebuah aktivitas yang sangat penting dalam menyelesaikan konflik,sehingga peran pengelolaan sebuah organisasi dibutuhkan keahlian menyelesaikan persoalan,maka semakin kita bersungguhsungguh kita akan mendapatkan hasil yang maksimal, jadi sebuah solusi inilah yang harus dipertimbangkan dalam berbagai hal agar kita menjadi yang menang dan sebagainya. ${ }^{18}$ Strategi seorang da'I adalah bagaimana metode serta upaya untuk menggunakan sasaran agar apa yang ia samapaikan bisa sampai pada para pendengar juga para melihat aktivitas dakwah sehingga tujuan dan harapannya bisa berjalan dengan optimal. ${ }^{19}$

Strategi dakwah Islam di era globalisasi : (1)Menerapkan ajaran tauhid dalam isi berdakwah,(2) menerapkan pada masyarakat tentang ajaran agama Islam sehingga masyarakat mengerti tentang ajaran agama Islam serta mau melaksanakannya dan mengamalkannya sehingga ada perubahan dalam kehidupan sehari-hari (3) menerapkan dakwah impratif pada anggota ikatan sosial kerukunan air sengak Curup Kabupaten Rejang Lebong ${ }^{20}$.

Tahap-tahap perencanaan strategi : (1) Bersungguh-sungguh dalam memahami pembuatan rencana,mengawasi rencana yang akan dilakukan,mengetahui anggota perencana dan dokumen orsos; (2) Menegaskan visi-misi; (3) paham dengan tempat tinggal,caranya tanggap terhadap berita yang diperlukan dalam perencanaan,memahami solusi dari pimpinan baik dari dalam maupun dari luar. Setuju dengan yang harus diutamakan. Caranya adalah menganalisa power dan ketidak berdayaan antara ancaman tantangan hambatan dan gangguan secara selektif; (5) Menulis solusi dengan langkah menulis rencana solusi yang harus dikaji ulang serta mencontoh konsep yang sudah ada; (6) Implmentasi solusi menjalankan aktivitas tahunan; dan (7) Mengarahkan dan memotivasi solusi dalam perencanan dakwah.

Demikianlah deskripsi bagaimana manajemen dan strategi dakwah pengajian ISK Air Sengak Rejang Lebong.

\section{Penutup}

Pengajian Ikatan Sosial Kerukunan Rejang Lebong berupaya untuk meningkatkan kualitas kehidupan yang bermartabat dan berperadaban,hidup berharkat pada lingkungan keluarga dan sekitarnya,baik didaerah dan dikampung juga ikut untuk mengembangkan pembangunan insan kamil yang didalamnya adanya kekuatan iman dan ketaqwaan kepada Allah subhanahuwataala untuk menjadi insan dalam masyarakat madani yaitu demokratis serta beraadilan sosial yang landasannya

\footnotetext{
${ }^{17}$ Abdul Wasit, Filsafat Dakwah (Jakarta: Rajawali Pers, 2013).

18 Suyadi, Strategi Pembelajaran Karakter (Bandung: Remaja Rosdakarya, 2013).

19 Awaludin Pimay, Paradigma Dakwah Humanis: Strategi Dan Metode Dakwah Prof KH Syaifudin Zubri. (Semarang: Rasail, 2005).

${ }^{20}$ Awaludin Pimay, Paradigma Humanis Strategi Dan Dakwab (Jakarta: RajaGrafindo Persada, 2001).
} 
dan diberi kemudahan dari yang maha kuasa,juga ketangguhan para anggota ISK untuk mencapai harapan organisasi.

Organisasi Isk dalam pelaksanaan pengajian dakwah Islamiyah,serta progres dakwahnya dan mengembangkan visi dan misi organisasi dalam melaksanakan aktivitas program-program kedepan serta melakukan kajian power serta kekurangan orsos,mengetahui ancaman tantangan dan hambatan disertai dengan strategi juga kebijakan dalam orsos dan memberi pembagian tugas-tugas kepada anggota yang sesuai dengan kemampuannya,memberikan kepada sumberdaya kekuatan yang ada dalam organisasi dan dikoordinasikan dengan kegiatan-kegiatan untuk mencapai harapan organisasi serta pengawasan pengelolaan yang berstandar.

Cara berdakwah Islamiah yaitu: (a) menerapkan ajaran tauhid di dalam isi dakwah,(b)menerapkan pada masyarakat tentang ajaran agama Islam sehingga masyarakat mengerti tentang ajaran agama Islam serta mau melaksanakannya dan mengamalkannya sehingga ada perubahan dalam kehidupan seharihari,(c)menerapkan dakwah impratif pada anggota ikatan sosial kerukunan air sengak.

Dalam pelaksanaan dakwah berkumpul semuanya anggota organisasi Isk Air Sengak dalam gedung Isk dari ketiga RT yang ada di kelurahan tersebut serta mengajak saudara kaum muslimin dan muslimat di sekitar.Strategi dalam bidang keagamaan,pertemuan secara berkala untuk mengagungkan ajaran Islam serta untuk mengembangkan dakwah Islam.

\section{Daftar Pustaka}

Abdul Wasit. Filsafat Dakwah. Jakarta: Rajawali Pers, 2013.

Abuddin, suwito Masykuri dan Armai. Integrasi Ilmu Agama Dan Ilmu Umum. Jakarta: RajaGrafindo Persada, 2005.

Afrizal. Metode Penelitian Kualitatif Sebuah Upaya Mendukung Penggunaan Penelitian Kualitatif Dalam Berbagai Disiflin Ilmu. Jakarta: Rajawali Pers, 2015.

Arifin M. Dan Barnawi. Manajemen Sarana Dan Prasarana Sekolah. Yogyakarta: ArRuzz Media, 2012.

Awaludin Pimay. Paradigma Dakwah Humanis: Strategi Dan Metode Dakwah Prof KH Syaifudin Zubri. Semarang: Rasail, 2005.

- Paradigma Humanis Strategi Dan Dakwah. Jakarta: RajaGrafindo Persada, 2001.

Fathurrahman, Murni Yanto dan Irwan. "Manajemen Kebijakan Kepala Madrasah Dalam Meningkatkan Mutu Pendidikan." Jurnal Konseling Dan Pendidikan 7, no. 3 (2019): 123-30. https://doi.org/http://doi.org/10.29210/138700.

Handoko, T.Hani. Manajemen. Yogyakarta: BPFE, 2004.

Hartani A.L. Manajemen Pendidikan. Yogyakarta: Laks Bang Pressindo, 2011.

Mgs. Nazarudin. Manajemen Pembelajaran Implementasi Konsep, Karakteristik Dan Metodologi Pendidikan Agama Islam Di Sekolah Umum. Yogyakarta: Teras, 2007.

Murni Yanto. "Manajemen Sekolah Dalam Pengelolaan Kegiatan Guru Bahasa Indonesia Di Sekolah Dasar." Jurnal Estetik 3, no. 1 (2020): 15-26. https://doi.org/DOI:10.29240/estetik.V31i.1479.

Purwanto, Iwan. Manajemen Strategi. Bandung: Yrama Widya, 2006.

Siswanto. Pengantar Mananajemen. Jakarta: Bumi Aksara, 2011. 
Suyadi. Strategi Pembelajaran Karakter. Bandung: Remaja Rosdakarya, 2013.

Syaiful Sagala. Konsep Dan Makna Pembelajaran. Bandung: Alfabeta, 2011.

Ula, S.Shoimatul. Revolusi Belajar. Yogyakarta: Ar-Ruzz Media, 2013.

Wahidin. Pengantar Ilmu Dakwah. Jakarta: Rajawali Pers, 2011.

Yanto, Murni. "Manajemen Dan Mutu Pembelajaran Bahasa Indonesia Di SMPN 4 Rejang Lebong." Jurnal Ar-Riayah 1, no. 2 (2017): 192. https://doi.org/DOI :http:/dx.doi.org/10.29240/jpd.v1i2-319. 
14 Jurnal Dakwah dan Komunikasi, Vol.6 No.1, 2021

\section{Halaman Ini Sengaja di Kosongkan}

